\title{
La arqueología \\ precientífica en el Perú \\ en el siglo xVIII
}

\section{Paula Ermila Rivasplata Varillas ${ }^{1}$ rivasplatavarillas@gmail.es}

The pre-scientific archeology in Peru

in the eighteenth century

\section{Resumen}

Este artículo indaga sobre el desarrolló de la arqueología precientífica en el Perú en el siglo XVIII; el método de estudio ha sido hermenéutico y heurístico. En el siglo XVIII, la arqueología precientífica fue practicada generalmente por ilustrados europeos que llegaron al Perú, a excepción del criollo Miguel Feijoo, quien casualmente hizo la primera representación gráfica de un corte estratigráfico arqueológico en la costa norte del Perú que se puede reconocer como tal entre 17631765, y que fue dada a conocer a través del obispo Baltasar Martínez Compañón.

Palabras clave: arqueología precientífica, siglo XVIII, Ilustración, Miguel Feijoo, Baltasar Martínez Compañón, Llano Zapata.

\section{Abstract}

This article tries to investigate if the prescientific archaeology was developed in Perú in the 18th century. The method of study has been hermeneutic and heuristic. The result would indicate us that in the 18th century, pre-scientific archaeology was carried out almost entirely by illustrated Europeans who came to Peru,

with the exception of the creole Michael Feijoo who by chance was the one that realized the first graphical representation of a stratigraphic "archaeological" cut on the north coast of Perú that can be recognized as such between 1763-1765 and that was announced through the bishop Baltasar Martínez Compañón.

Key words: pre-scientific archaeology, 18th century, Enlightenment, Miguel Feijoo, Baltasar Martínez Compañon, Llano Zapata.

1 Universidad de Sevilla, Departamento de Historia de América, España. Doña María de Padilla, s/n, 41004, Sevilla, España. 
Los antecedentes de la arqueología científica se fueron forjando en el siglo XVIII en Europa y en América. Surgieron nuevas miradas hacia las antigüedades y se expandieron rápidamente por el orbe. ${ }^{2}$ El gusto que la elite ilustrada desarrolló por el anticuarismo y "las antiguallas" hizo que proliferaran las excavaciones para buscar las curiosidades de los antiguos. Toda excavación es destrucción y, al hacerse mal, sólo por sacar la obra de arte o la curiosidad, se destruyen contextos culturales aún más importantes que los objetos en sí. Sin embargo, algunos excavaron lentamente y con cuidado, describiendo en libretas de campo el corte estratigráfico realizado. ¿Por qué lo hicieron así? Quizá para obtener más información sobre los objetos hallados y dibujados. Esta actitud respondería a los nuevos modos e ideas de mirar el pasado que estaban naciendo a partir del trabajo de campo. Las conclusiones de estos trabajos reflejarían las ideas, las creencias, los prejuicios del mundo en que estaban inmersos los primeros arqueólogos, del que difícilmente podían separarse.

El marco ideológico en el que se desarrolla este trabajo es el de la Ilustración, en que se estaba forjando una visión progresista y evolutiva de la historia humana. ${ }^{3}$ No se había desarrollado aún ninguna técnica científica para calibrar una cronología relativa de los objetos encontrados, pero ya estaba vigente el gusto por el coleccionismo, y se necesitaba de alguna manera datarlos aproximadamente. ${ }^{4}$ En este punto se indicaría que en el caso español el coleccionismo había estado bastante arraigado en la dinastía de los Habsburgo, igualmente que en la naciente dinastía borbónica, la que al llegar al trono español promovió expediciones científicas con cuyos productos fueron aumentando paulatinamente sus colecciones. ${ }^{5} \mathrm{De}$ esta manera, en el siglo XVIII el Estado sería el promotor directo de las expediciones científicas y de las colecciones ilustradas. Ese coleccionismo se orientó hacia objetos arqueológicos y etnográficos sin importar su valor material, pero que fuesen suficientemente peculiares o represen-

\footnotetext{
Renfrew, Arqueología, p. 19.

Trigger, Historia del pensamiento, pp. 63-66. Glyn, Historia de la arqueología, p. 90; Almagro-Gorbea, De Pompeya, pp. 18-19. Triger, Historia del pensamiento, 67. Los anticuarios dieron los primeros pasos en el descubrimiento del concepto de cronología relativa de todos los hallazgos para los que no se disponía de registros históricos. Cabello, "La formación", p. 304. La dinastía de los Habsburgo recibió las "antiguallas" como presentes y tenía sus colecciones indianas, pero algunas se habían destruido en los incendios de los palacios reales que las albergaban. También se mandó recopilar datos, transcribir documentos indígenas y redactar crónicas durante los siglos XVI y XVII.
}

4 
tativos del lugar del que procedían. Ese interés que la Corona mostraba por las "curiosidades" como las piezas arqueológicas y los objetos del costumbrismo etnográfico llegó a la elite criolla y española en las Indias y no tardaron algunos de sus representantes en emprender cruzadas de búsqueda y extracción de antigüedades para mandarlas a la península y así hacerse notar y ganarse favores y de paso alguna prebenda. ${ }^{6}$

Teniendo en cuenta lo precedente, este artículo trata sobre la arqueología precientífica, a la que Colin Renfrew se refiere como la fase especulativa de la arqueología ${ }^{7}$ y que también podía catalogarse como arqueología clásica, tal como la denomina Bruce Trigger. ${ }^{8} \mathrm{El}$ interés por la antigüedad clásica estaba presente en el siglo XVIII entre la elite intelectual, al punto que surgieron sociedades dedicadas a su estudio. Por ejemplo, en Londres, la Sociedad de Diletantes, fundada en $1714,{ }^{9}$ apadrinó económicamente investigaciones en la zona del Egeo. El interés por el arte clásico griego y romano hizo que se estudiara lo antiguo, campo en el que destaca la obra de Johann Winckelmann Historia del Arte Antiguo (1764). ${ }^{10}$ Así también, los estudiosos que acompañaron a la expedición napoleónica en Egipto en 1798 y 1799 darían interesantes frutos sobre la antigüedad egipcia en el siglo siguiente. ${ }^{11} \mathrm{Y}$ no se debe olvidar la pléyade de viajeros y excavadores anticuarios "científicos" dieciochescos.

El objetivo principal del presente estudio es indagar los antecedentes de la arqueología en el siglo XVIII en el Perú. La pregunta sería si se desarrolló algún tipo de arqueología precientífica y cuáles fueron sus métodos y técnicas, y también se buscaría escudriñar la historia de la arqueología precientífica en el Perú en el contexto sociohistórico de la época en el país y en el mundo. Para ello se han empleado la heurística y la hermenéutica en la documentación primaria obtenida del Archivo General de Indias Estado, 75, N.40, 25-06-1798. Memorial de Juan del Carmen Fernández del Castillo y Maldonado al Príncipe de la Paz exponiendo sus servicios y solicitando la intendencia de Trujillo o una de las subdelegaciones en Hualgayoc, Cajamarca o Piura. Dice que ha remitido a Lima un cajón con varios cantaritos y piezas de las Guacas para que se las remitan a su excelencia. desarrollado la arqueología como ciencia, ni siquiera qué influjo hubieran alcanzado en la sociedad de su tiempo las ideas del historiador de arte Winckelmann, a quien se atribuye la organización científica de la arqueología".

11 Trigger, Historia del pensamiento, p. 47. 
(AGI), los dibujos de Miguel Feijoo y las acuarelas de la obra del obispo de Trujillo en el virreinato del Perú, don Baltasar Jaime Martínez Compañón, entre las que hay una de un corte estratigráfico de un túmulo funerario en la costa norte peruana. Paralelamente, en los nacientes Estados Unidos, Tomás Jefferson realizó la reconocida primera excavación "científica" en Virginia en 1784. Su objetivo era averiguar si los túmulos que estaban en sus propiedades habían sido hechos por los indios o por alguna raza mítica, tal como se creía. ${ }^{12}$ Descubrió que habían sido utilizados como enterramiento de indios por mucho tiempo. Ya desde comienzos del siglo XVIII se estaban llevando a cabo gran número de excavaciones en distintos lugares, porque el interés por "las antiguallas" iba creciendo.

En América hispana y en el Perú, Carlos III influyó positivamente para que un incipiente anticuarismo surgiera y destacara por su carácter grandilocuente y por la belleza y el prestigio de sus resultados. El interés del monarca databa de cuando fue rey de Sicilia, entre 1738 y 1759. En esa época auspició y apoyó la más grande operación arqueológica, sin precedentes por su magnitud y dificultad en el siglo XVIII, para conocer la Antigüedad: las excavaciones en Herculano, enterrada por las lavas del Vesubio. ${ }^{13}$ Oficiales ingenieros españoles excavaron túneles subterráneos en un material consolidado bastante duro. ${ }^{14}$ Los objetos (estatuas de mármol, terracota, tejidos, murales, papiros quemados) que se encontraron fueron depositados en el Real Museo Herculano en Nápoles desde $1751 .{ }^{15}$ La producción literaria consistió en informes, libros, diarios, dibujos, mapas, planos, catálogos e incluso se inventó una manera de abrir rollos de papiro carbonizados para leer su contenido. ${ }^{16}$ Diez años más tarde, en 1748, el rey auspició excavaciones en Pompeya, que se hicieron horizontalmente por su inmensidad y por estar cubierta de ce-

Wheeler, Arqueología, p. 55: "En Jefferson no sólo es importante la excavación sino el informe que presentó la descripción de cada capa del túmulo excavado". Trigger, Historia del pensamiento, p. 74. te desde 1738, siguiendo las ordenanzas del cuerpo de ingenieros, lo que supone una importante diferencia con el resto de las excavaciones del siglo XVIII. Se registran los hallazgos y se hace un detallado diario de las excavaciones para redactar una relación de las antigüedades". 
niza, material de difícil evacuación, así que lo que se descubría se volvía a enterrar. También mandó excavar en Eusabia, Pozuoli y otros lugares.

En este contexto, en 1759 Carlos de Borbón fue elegido rey de España y tuvo que abandonar Nápoles para dirigirse a la península, pero su espíritu ilustrado fue motivo de copia y emulación. Sus súbditos sabían el apego y gusto que tenía el rey por las antigüedades y el coleccionismo. Al subir al trono, propició los "viajes literarios" de connotados estudiosos para descubrir el mundo con nuevas miradas más científicas y utilitarias. Las noticias de la excavación de ciudades romanas llegaron a oídos de los estudiosos y personas cultas en el Perú y otras partes de la América hispana y empezó un frenesí por la excavación y exploración de sitios antiguos. Esta tendencia podría explicar por qué un arequipeño como Miguel Feijoo, ilustrado y perteneciente a una familia benemérita del Perú, desarrolló ese gusto por una excavación más ordenada, describiendo las capas edafológicas tanto como antropológicas que veía en su calicata, tal como lo hizo en la huaca Tantalluc en la costa norte peruana en 1765. Fue un trabajo que el obispo de Trujillo, Baltasar J. Martínez Compañón, agregó en la obra que redactó sobre la visita a su obispado.

Así, observamos que en el Perú las ideas ilustradas llegaron rápidamente y encontraron caldo de cultivo entre su intelectualidad laica y religiosa. El interés que despertaban las ruinas y "antiguallas" ya no era solamente económico, sino también estético y sobre todo intelectual y cognitivo. La técnica aún no se había desarrollado, pero las preguntas se hacían e incluso algunos empezaron a resolverlas excavando, haciendo planos y escribiendo en diarios lo que encontraban, describiendo los estratos de sus excavaciones. La observación y el pensamiento cognitivo eran sus mejores herramientas. Todo el material extraído se enviaba a gabinetes de curiosidades en la Metrópoli para halagar la afición que el rey había introducido y que compartían algunos de sus súbditos.

Sin embargo, pocos intelectuales fueron los que llevaron un seguimiento de la excavación que hacían para extraer las curiosidades; más bien se contentaban con dibujos bien hechos e informes detallados, como fue el caso de Antonio de Ulloa en el libro Relación histórica del viaje a la América Meridional que publica con Jorge Juan en $1748 .{ }^{17}$ Ulloa hizo para esta obra planos en vista de planta y frontal de arquitectura precolombina y dibujos detallados de los objetos encontrados sobre todo en entierros. No describía el proceso de la excavación ni la modalidad empleada, sólo

${ }_{17}$ Juan y Ulloa, Relación histórica, t. I, pp. 616-614. Trigger, Historia del pensamiento, p. 65. Según este investigador, los arqueólogos ilustrados, salvo excepciones, ignoraron los datos arqueológicos. 
mostraba con sumo detalle los objetos encontrados, descontextualizados de su medio.

En el siglo XVIII, las excavaciones buscaban descubrir artefactos y extraer los objetos preciosos, y tal como indica Michele Ruggiero en Herculano, "los estudios y la erudición de aquel tiempo no iban mucho más allá de la interpretación del arte figurativo y del conocimiento material de las lenguas doctas, ni la noble ambición de aquel príncipe superaba el propósito de poseer un rico museo". ${ }^{18}$ Sin embargo, poco a poco, algunos detectaron que el perfil estratigráfico aportaba información y permitía descubrir los cambios que habían tenido lugar en el tiempo por el principio de superposición, lo que dio pie a un perfil vertical que muestra las capas o secuencias que se habían acumulado a lo largo del tiempo. Pero las excavaciones se hacían mal y se destruían los datos o se malinterpretaban.

\section{Contexto histórico}

\section{Las primeras impresiones de "las antiguallas" andinas}

El descubrimiento y la primera colonización de América despertaron gran interés y curiosidad sobre el mundo indígena, lo que se tradujo en la redacción de muchas crónicas sobre la historia y las costumbres de los indios y en el envío de objetos de diversa naturaleza a la Corona, nobleza, Iglesia y particulares. ${ }^{19}$ En un comienzo resultaba increíble para los españoles creer que los indios hubiesen sido capaces de desarrollar sociedades tan complejas, cuyas evidencias arquitectónicas y de ingeniería, estaban a la vista. Por ejemplo, al conquistador y cronista Pedro Cieza de León (1518-1554), para quien "fuerte" y "grande" fueron los adjetivos reiteradamente usados para describir las muestras arquitectónicas encontradas en el Perú, le resultaba imposible creer que tales construcciones hubiesen sido realizadas por indios y no por "hombres barbados"; es decir antiguos europeos representados en la iconografía precolombina tiahuanaquense: "Son tan grandes que parecen pequeños gigantes y [...] tienen forma de vestimentas largas, diferenciadas de las que vemos a los naturales de estas provincias". ${ }^{20}$

A los clérigos españoles tampoco les resultaba creíble que tales monumentos hubiesen sido hechos por indios. Es más: estaban fir-

\footnotetext{
18

19

20

Fernández Burga, Carlos III, p. 151.

Cabello Carro, Coleccionismo, p. 23: las colecciones que pretendían servir de testimonio y justificación solían ir destinadas a la Corona.

Cieza de León, La Crónica, pp. 367-368.
} 
memente convencidos de que al Nuevo Mundo y en concreto al Perú había llegado un hijo de Noé después del diluvio, o un apóstol, santo Tomás, para divulgar la palabra de Dios, pues las ruinas inmensas que encontraban se consideraban testigos de ambas presencias en la región andina. La Suma y narración de los Incas de Juan de Betanzos (1551) y el Señorío de los Incas de Pedro Cieza de León (1553) registran presunciones sobre una evangelización prehispánica. A fines del siglo XVI, los eclesiásticos se lanzaron tras el rastro de santo Tomás estimulados por el ejemplo del arzobispo Mogrovejo, que había consagrado públicamente las huellas de los pies y las rodillas del santo en Chachapoyas, incluso cerca de Pachacamac creyeron haber descubierto las huellas del apóstol. ${ }^{21}$

Pero pronto entendieron que era necesario valorar al enemigo para que la proeza de la conquista fuese más ensalzada y justificada, de tal manera que las construcciones antiguas, al ser consideradas trofeos de guerra, ennoblecieran al conquistador por su belleza y magnitud. Pero una cosa era la política y otra el sentir de muchas personas que sentían genuina admiración por la cultura indígena y la hicieron pública a través de libros. Fue el caso del inca Garcilaso de la Vega, uno de los primeros mestizos del Perú, que en sus Comentarios reales (1609) resalta la innegable obra monumental y urbanística inca. Él la exalta al punto que le resulta imposible creer, por su grandiosidad y perfección, que hubiesen sido erigidas no ya por indios, sino por seres humanos. La siguiente es una descripción de la fortaleza de Sacsayhuamán, perteneciente a la cultura Inca:

La obra mayor y más soberbia que mandaron hacer para mostrar su poder y majestad fue la fortaleza del Cuzco, cuyas grandezas son increíbles a quien no las ha visto y al que las ha visto y mirado con atención le hacen imaginar y aun creer que son hechas por vía de encantamiento y que las hicieron demonios y no hombres; porque la multitud de las piedras, tantas y tan grandes, como las que hay puestas en las tres cercas (que son más peñas que piedras), causa admiración imaginar cómo las pudieron cortar de las canteras de donde se sacaron, porque los indios no tuvieron hierro ni acero para las cortar ni labrar, pues pensar cómo las trajeron al edificio es dar en otra dificultad no menor, porque no tuvieron bueyes, ni supieron hacer carros, ni hay carros que las puedan sufrir, ni bueyes que basten a tirarlas [...] pues pasar adelante con la imaginación y pensar cómo pudieron ajustar tanto unas

21 Varios, Antigüedades, pp. 143-153. 
piedras tan grandes, que apenas puedan meter la punta de un cuchillo por ellas, es nunca acabar. ${ }^{22}$

Las primeras impresiones de perplejidad pronto dieron paso a una serie de reacciones antiindigenistas y otras de profunda admiración, como ya hemos visto. ${ }^{23}$ Una vez asentado el virreinato del Perú con sus instituciones civiles y religiosas, se acrecentó el fanatismo religioso con la extirpación de idolatrías y la presión económica del vencedor sobre el vencido, lo que llevó a la paulatina destrucción de la cultura precolombina con la imposición de la nueva que dio paso al sincretismo o mestizaje cultural.

\section{La destrucción y el reúso de las huacas o contextos funerarios precolombinos}

El saqueo, la destrucción en busca de metales preciosos, la postración del indígena sujeto a trabajos forzados y el pago de tributos fueron consecuencias de la dominación española sobre los indios. Eso se tradujo en la destrucción de gran parte del patrimonio material indígena no sólo por la búsqueda de oro y plata, sino por la imposición de ideas religiosas foráneas. Todo esto formó parte del proyecto colonial de dominación del pueblo indígena, gestado desde la Corona y realizado por sus caudillos.

En este contexto, la búsqueda de botines de guerra hizo común la excavación, sustracción y expoliación de los ajuares funerarios, que se convirtió en práctica usual desde el siglo XVI. Se saquearon los templos, las ciudadelas, pero también las necrópolis, donde se encontraron los más preciados botines en oro, plata y piedras preciosas. ${ }^{24}$ Algunos indios testigos de las ansias con que anhelaban semejantes objetos, los enterraban, derretían o arrojaban a las lagunas. ${ }^{25}$

Las excavaciones o "huaqueos" con fines lucrativos desde el siglo XVI consistían en partir por la mitad las pirámides u horadarlas para llegar a las tumbas y sus ajuares. ${ }^{26}$ Un despojo celebre tuvo lugar en el templo

\footnotetext{
22

23

24

Vega, Los Comentarios, p. 180.

Serna Arnaiz, “Censura”, p. 347.

AGI. Quito, 209, L.1, F. 66R-66V, 06-04-1588. Real cédula al presidente y oidores de la Audiencia de Quito para que lleguen a un acuerdo con los indios de Tomavela y les eximan de la mita y a cambio descubran una guaca de gran riqueza que al parecer hay en dicho lugar.

25

26 Rivero y Tschudi, Antigüedades, p. 170.

Las Casas, Los tesoros, p. 475. Huaca también puede significar adoratorio o casa de oración, mina, tesoro o cosa admirable. Se deriva del verbo quechua huacani,
} 
de Pachacamac, en la costa central del Perú. Se obtuvieron 27 cargas de oro y 2000 marcos de plata procedentes de la orfebrería precolombina, que fue fundida para obtener el mineral y proceder a su repartición. ${ }^{27}$ Dos sitios destacaron por la magnitud de esta actividad depredadora: la costa norte del Perú, donde se desarrollaron las culturas Mochica y Chimú, y los valles interandinos centrales, específicamente Cuzco, sede de la cultura inca.

La búsqueda de tesoros y de otros objetos que se encontraban en abundancia en los entierros propició la destrucción de muchos de esos lugares, incluso desviando ríos para que sus aguas erosionaran las pirámides truncadas, en el caso de las ubicadas en la costa norte peruana. ${ }^{28}$ Las riquezas encontradas en las necrópolis precolombinas llamadas huacas dieron origen a litigios y a la pérdida de éstas. ${ }^{29}$

También la Iglesia participó en la destrucción de huacas con bastante frenesí durante la denominada "extirpación de idolatrías" en los siglos XVI y XVII. En este caso, la destrucción era justificada por la Iglesia

que significa llorar; entonces huacas son los lugares (sepulturas y templos) donde se llora. Llano Zapata, Memorias, p. 199: "Una guaca puede ser algo natural o construido por el hombre: el sol, luna, estrellas, momias del inca, bloques de piedras, monolitos, tejidos, etc". AGi. Patronato 192, N.1, R.4. 1534. Cabildo Jauja: fundición oro y plata de Atahualpa. Llano Zapata, Memorial histórico, p. 391. AGI. Indiferente, 606, 24-10-1584: Real cédula a fray Francisco del Castillo, descalzo de la orden franciscana, haciéndole merced del $4 \%$ de lo que se descubriere y sacare de una "guaca" o enterramiento de indios en la provincia de Jauja en el Perú. AGi. Lima 565, L. 2, 07-12-1537. Real cédula de D. Carlos al gobernador de la provincia del Perú, por (la que lo insta que) vea y resuelva en el asunto de Francisco Chávez y María de Escobar su mujer, que fue casada con Martín Estete, sobre cierto oro y plata de una huaca de un cacique de la provincia de Chimo y se pleitea sobre si pertenece al dicho Martín Estete o a la Real Hacienda. AGI. Justicia, 404, N,1. 19-05-1564 a 28-09-1564, Alonso Zarco contra Francisco de Escobar y otros. Alonso Zarco, vecino de Trujillo, presenta ante el Consejo recurso de segunda suplicación de la sentencia dictada por la Audiencia de Lima en el pleito que ha seguido contra Francisco de Escobar, el bachiller Pedro Muñoz de Arraya, abogado Baltasar Castellanos, Miguel de Villalobos y otros sus consortes, vecinos todos de Trujillo, sobre los derechos de pertenencia de la huaca de Yumayuguán, en el término de dicha ciudad, y el tesoro que se sacó de ella.

29 AGI. Justicia, 404, N1. 1564. Autos entre partes. El litigio sobre la propiedad de la huaca Lomayahuana o Yumayuguán entre 1558 que concluyó en 1564. Esta huaca se excavó por muchos años y se extrajeron objetos de oro y plata que despertaron la codicia de propios y extraños. 
en razón de los dogmas de fe. ${ }^{30}$ La destrucción comprendió todo aquello considerado sacrílego, como los ídolos de madera, murales, etc. Algunos religiosos describían lo que destruían o combatían, tanto lo material como lo inmaterial (las costumbres consideradas impías). ${ }^{31}$ De tal manera, ha quedado información al respecto que constituye en la actualidad una indudable ayuda para los investigadores.

Otra causa de destrucción fue el valor comercial que los ajuares funerarios extraídos de los entierros llegaron a tener por la buena calidad del tejido precolombino. En efecto, el 2 de diciembre de 1580 se denunció que el algodón usado para hacer jubones provenía de las ofrendas que contenían los fardos que utilizaban los indios para envolver a sus muertos y que se obtenía al escarbar en las huacas o antiguos cementerios precolombinos. El cabildo limeño se había informado de que los sastres, calceteros y juboneros, en las ropas y calzas que hacían, utilizaban "algodón de huacas lo cual es muy enfermo, demás del horror e olor que tiene de ser algodón sacado entre muertos y que convenía poner remedio en que no se gaste tal algodón". ${ }^{32}$ Mandaron que ningún sastre utilizara algodón de huacas en ninguna ropa, jubón ni sayo ni calzas en poca ni mucha cantidad, so pena, si fuera español, de pérdida de la tal ropa, y que si lo vendiera tendría que devolver el importe, además de sesenta reales de pena, aplicados todo por tercias partes al juez, al denunciante y a las obras públicas. Si fuera indio que tuviese tienda, en la primera infracción pagaría la mitad de la pena y en la segunda se le quitaría la tienda, y si fuera negro horro o mulato, la misma pena que los españoles, y a la segunda se le quitaría la tienda.

Los huaqueos se realizaron durante todo el periodo colonial porque "en todas partes del Reino, se sabe haber tesoros ocultos y raros". ${ }^{33}$ Las

30 González, "La crónica", p. 13: "La penetración del cristianismo en América está atravesada por el espíritu de cruzada, que es la guerra de la Cruz cristiana contra los infieles, sus reyes y sus dioses [...]. A las Indias y al Perú se venía ‘al encuentro con el demonio'".

31 Llano Zapata, Memorias, pp. 376-377. La práctica de dibujar y describir todo lo considerado idolatría antes de su destrucción. Así, de orden del arzobispo de Lima don Gonzalo de Ocampo, el licenciado Duarte Fernández visitó Calango, cerca de Lima, donde se encontraban piedras con figuras que el visitador consideró "el origen de idolatrías que allí ejercitaban los indios en fuerza de la tradición, las hizo picar y romper, habiendo antes estampado los caracteres y signos [...] y debe estar en el libro de visitas del arzobispado de Lima de los años de 1543". Bertham, Libros de cabildo de Lima, Libro Noveno, años 1579-1583. AGI. MP-Libros_Manuscritos, 1,8. Descripción de la ciudad y provincia de Trujillo.06-12-1761. A mediados del siglo XVIII, Miguel Feijoo, funcionario y escritor, indica- 
pirámides precolombinas también eran destinadas a otros usos. Generalmente se construían templos en sus pináculos, pero también podían servir para fortines o almacenes. Por ejemplo, se pretendió utilizar una huaca en las afueras de Lima para el almacén de pólvora limeño por "las ventajas del terreno para la mayor seguridad contra enemigos". ${ }^{34}$ Un plano que se encuentra en la sección de mapas y planos en el Archivo General de Indias, hecho por el oficial ingeniero Mariano Pusterlaen en 1777, muestra la adecuación de la infraestructura precolombina a su nueva función: un fortín y almacén de pólvora. ${ }^{35}$

\section{La Ilustración y los cambios en el régimen intelectual que propiciaron el nacimiento de la arqueología precientífica en el contexto sociohistórico de la época colonial}

Después de doscientos años, la visión que los vencedores tenían de los vencidos no había cambiado, incluso siempre estaba latente el temor de un levantamiento definitivo contra el régimen. Sin embargo, lentamente se fueron notando cambios respecto del clima intelectual imperante a principios del siglo XVIII. La causa fue la influencia de la Ilustración, que permitió al poder central tener una mirada más condescendiente si no con el indígena contemporáneo, al menos con sus antepasados, y propició que se visualizara el valor de las "antiguallas" prehispánicas. En esta etapa de transición que caracteriza al siglo XVIII conviven lo anacrónico y lo nuevo en un mismo escenario. Esta ambigüedad se aprecia cuando la Corona, a través de sus instituciones, no permitió que se escribiera la historia de las poblaciones andinas, ni sus logros como civilizaciones por criollos y mestizos, pero mandó expediciones científicas a inspeccionar y recopilar información económica y étnica, incluso permitió que otras potencias lo hicieran, como Francia.

ba: "Se discurre que haya en estos valles (costa norte peruana) algunos tesoros ocultos, pero a mi juicio con más razón se hallarían en mayor copia en la ciudad del Cuzco e inmediatas provincias, como asiento principal de los incas a quienes dedicaban sus súbditos el oro y plata como menaje y adoración".

AGI. MP-Perú _ Chile, 75. Guaca. Almacén de pólvora (Perú).08-11-1777. "Plano de guaca, situada entre las chacras de Pando y Maranga a 3 quartos de legua al E.N.E. próximamente del Fuerte el Real Felipe del Callao de Lima; que demuestra el proyecto de un Almacén para Pólvora; su cuerpo de guardia; y defensas adaptables a las ventajas del terreno, para la mayor seguridad del enemigo". Mariano Pusterla. Escala para el plano de cuarenta varas, los $70 \mathrm{~mm}$. 
Asimismo, el racionalismo en el pensamiento se fue imponiendo paulatinamente en el siglo XVIII. Las ideas de Bacon y Descartes muy tímidamente entraron en el virreinato peruano, pues difícilmente superaron la férrea censura de la Inquisición. Durante el gobierno del virrey Amat y Junyet (1759-1788) se introdujeron ideas modernistas y de evolución cultural con una fuerte atracción eurocentrista entre los intelectuales de la elite peruana. El desarrollo de las ciencias, principalmente las matemáticas y la medicina, fue impulsado desde la metrópoli. ${ }^{36} \mathrm{~A}$ finales del siglo XVIII se percibió al menos en Lima, la capital del virreinato del Perú, la aceptación parcial del racionalismo entre algunos de sus intelectuales, pero continuó imperando el escolasticismo.

En esta etapa de transición continuaron las excavaciones de túmulos precolombinos para saquearlos, aunque en menor medida simplemente por el hecho de que ya era más difícil encontrarlos, o porque se invertía mucho tiempo, dinero y esfuerzo para hacerlo y era tan poco lo obtenido que no cubría ni los gastos. Sin embargo, surgió un nuevo interés intelectual por los entierros que propició la misma Corona, y funcionarios de distintas partes del virreinato peruano enviaban periódicamente objetos precolombinos a la metrópoli; el caso más famoso es el del obispo de Trujillo, Baltasar Martínez Compañón. Todo ello favoreció los coleccionismos europeos. No sólo destacaron en el interés por las culturas precolombinas funcionarios de la Corona española, sino también expediciones científicas europeas que invirtieron parte de su tiempo en analizar, excavar, dibujar, escribir sus pareceres sobre los monumentos y restos de materiales precolombinos. Destacaron la expedición franco-española para la medición de un grado del meridiano terrestre, con figuras tan renombradas como la de Jorge Juan, Antonio de Ulloa y Charles-Marie de La Condamine; la expedición botánica al Perú y Chile de Ruiz y Pavón de parte española, ${ }^{37}$ y Dombey de parte francesa; ${ }^{38}$ y la expedición de Alejandro

36 Alcina, Antropólogos, p. 28. En el siglo XVIII, en Europa y particularmente en España, el desarrollo de la ciencia, el modernismo "no supo aprovechar del humanismo renacentista todo lo que tenía de valioso, como la admisión de la variabilidad cultural y del relativismo a la manera en que lo hizo Bartolomé de las Casas", lo que constituyó un verdadero retroceso frente a lo logrado por algunos cronistas del siglo XVI. a Antonio Valdés, secretario de Estado de Marina, Guerra, Hacienda, Comercio y Navegación de Indias que el botánico José Pavón envió un cajoncito con las producciones de la montaña y manufacturas de los indios, con una lista adjunta.

38 AGI. Contratación, 5523, N.2, R.195, 17-10-1777. Expediente de información y licencia de pasajero de Indias a Hipólito Ruiz, botánico, con José Pavón, botánico, José Dom- 
Malaspina, con personalidades tan destacadas como Tadeo Haenke, Antonio Pineda o Felipe Bauza. ${ }^{39}$ Como indica Cabello Carro, "si no hubiera habido (una carrera comercial ultramarina) y una nueva concepción cultural volcada sobre el hombre, y por ende, en la ciencia (la Ilustración), no habría sido posible el nacimiento de gabinetes científicos con vocación coleccionista". ${ }^{40}$

Así, el conocimiento que tenemos sobre antigüedades peruanas en el siglo XVIII se debió a extranjeros ligados a expediciones científicas, también a algunos visitadores eclesiásticos e intelectuales que enviaban informes minuciosos sobre antigüedades y objetos precolombinos a colecciones reales. Lamentablemente, los intelectuales criollos y mestizos no tuvieron la libertad ni el estímulo para hacer lo mismo, pues en el siglo XVIII la Real Academia de Historia no otorgaba licencia para imprimir una historial general del continente americano, salvo algunas excepciones. Igual comportamiento tuvo el Consejo de Indias, que se opuso a la publicación de obras sobre ciencias físicas e históricas de autores americanos. ${ }^{41}$

A pesar de ello, a finales del siglo XviII la Ilustración hizo que el interés por las antigüedades precolombinas fuera cada vez mayor, y se hizo habitual el envío de cerámica, textiles y artesanía precolombinas como curiosidades ${ }^{42}$ De esta manera, a pesar de la censura, la apreciación por las antigüedades peruanas también se dio entre algunos intelectuales criollos peruanos como Llano Zapata. Se tiene que entender que la valoración positiva estaba en el pasado precolombino, no en los indígenas del siglo XVIII, los cuales fueron prácticamente ignorados por la elite intelectual.

El caso de Llano Zapata, un destacado representante de la Ilustración virreinal, necesariamente estaría imbricado en la justificación histórica de los criollos de su identidad territorial. A finales del siglo XVIII algunos intelectuales criollos nacidos en las colonias estarían buscando forjar,

bey, médico, natural de Francia, José Brunete, dibujante, e Isidro Gálvez, dibujante, al Perú. secretario de Estado. Envío de objetos indígenas en 1772 dirigido al príncipe de Asturias; comunica la remisión de dos pequeños cajones y un envoltorio que contienen varios ídolos, animales, alhajas de oro y plata de los antiguos indios, pájaros de pluma, una alfombra de las mismas, en partida de registro con destino al gabinete del príncipe de Asturias, nota suelta acuse de recibo. 
construir y valorar una incipiente identidad arraigada en la tierra donde nacieron, precisamente en la época en que un criollo realizó el primer corte estratigráfico documentado en la costa norte del virreinato peruano.

Las autoridades indianas estaban obligadas a hacer visitas de sus territorios para tener informada a la Corona. Destacan algunos de estos trabajos, como el del corregidor de Trujillo, el criollo Miguel Feijoo, en la descripción de su corregimiento en 1760, en la que hace entrever el pasado longevo y glorioso de esa área, quizá buscando expresiones de singularidad del territorio ocupado. Otro trabajo notable fue obra de Martínez Compañón, quien trató de documentar, conocer y detallar las costumbres y el pasado del territorio del que era obispo. También destaca el coronel de milicias español Gregorio de Cangas, quien a título personal escribió una Descripción dialogada de los pueblos y costumbres del Perú en el siglo XVIII en $1780 .{ }^{43}$

El culmen de este proceso de desarrollo precientífico de la arqueología peruana, que ya estaba configurado y claramente definido entre algunos de los arqueólogos precientíficos en el mundo de aquel entonces, lo ejemplificaría Miguel Feijoo, quien al realizar el primer corte estratigráfico documentado debió haber entendido que una excavación y una estratigrafía lo más precisa posible era necesaria para poder responder a la mayor cantidad de preguntas en cuanto a los túmulos excavados. En aquel entonces se presentía que toda excavación era destrucción y, por ser única esa acción, se trataba de extraer la mayor información posible de ella.

\section{Arqueólogos precientíficos que describieron antigüedades}

del Perú en el siglo XVIII

\section{Viajeros}

1. El sacerdote francés Louis de Feuillée nació en Mane en 1660 y murió en Marsella en 1732. Fue matemático, botánico y corresponsal de la Academia Real de Ciencias. Viajó a las Indias con fines científicos y geográficos, patrocinado por Luis XIV de Francia, de 1707 a 1712; hizo un recorrido a lo largo de las costas de América del Sur para realizar observaciones de tipo botánico y matemático, pero también se interesó por las antigüedades precolombinas. En su libro Journal des observations physiques, mathématiques et botaniques faites par l'ordre du Roi sur les côtes orientales de l'Amérique Méridionale... depuis l'année 1707 jusques en 1712, publicado en 1714, describe sitios arqueológicos en la costa central,

${ }_{43} \mid$ Cangas, "Descripción”, pp. 245-335. 
entre los que destaca Pachacamac. No indica haber participado en excavaciones. Ante cualquier duda, interrogaba a los lugareños indígenas sobre la funcionalidad y el uso de los monumentos. La metodología empleada para conocer la cultura material precolombina fue la observación y las fuentes orales, estableciendo contactos con las poblaciones autóctonas colindantes a los yacimientos.

2. Amédée-François Frézier nació en Chambéry, Francia, en el año de 1682. Militar e ingeniero de prestigio, fue enviado por orden real para hacer un reconocimiento de la situación de las plazas fuertes en las costas de Perú y Chile, misión que cumplió entre 1712 y 1714. A su paso por el litoral pudo apreciar las ruinas de Pachacamac, descritas en su obra Relation des Voyages de la mer de Sud.

3. Antonio de Ulloa, en el libro Relación histórica del viaje a la América Meridional que escribió con Jorge Juan, publicado en 1748 a sólo diez años del inicio de las excavaciones en Herculano por Carlos de Borbón, incluyó en la parte que le tocó redactar antigüedades encontradas en el Ecuador. Ulloa hizo planos de construcciones precolombinas de la zona y otras láminas de los objetos encontrados en los enterramientos, empleó tipologías y dedujo acertadamente que eran construcciones incas, aunque en aquella época no se conocía más que de éstos.

\section{Funcionarios}

1. Don Baltasar Jaime Martínez Compañón y Bujanda, natural de Navarra, fue nombrado chantre de Lima en $1768 .{ }^{44}$ Diez años más tarde fue nombrado obispo de Trujillo en el virreinato del Perú por el papa Pío VI, a solicitud del rey Carlos III. Permaneció en el cargo hasta 1791, cuando fue nombrado arzobispo de Santa Fe del virreinato de Nueva Granada. En 1782 empezó una visita oficial en su obispado que duró cinco años, hasta 1786, y cumplió este trabajo de manera eficiente, interesándose -como buen ilustrado- por todo lo que tenía que ver con su diócesis. La costa norte peruana, territorio del obispado asignado a Compañón, había sido cuna de importantes civilizaciones precolombinas: moche, vicus, chimú e inca. La diócesis de Trujillo comprendía desde la costa central del Perú hasta el límite con el Ecuador, abarcando la cordillera de los Andes y parte de la selva amazónica. La visita que realizó en su diócesis, acompañado de dibujantes, dio como resultado la producción

\footnotetext{
44 AGI, Contratación, 5511B, N.2, R.12, 1768-1-25. Expediente de información y licencia de pasajero a indias del doctor Baltasar Jaime Martínez Compañón, presbítero, chantre de la Iglesia metropolitana de Lima, con sus criados.
} 
de 1411 acuarelas (planos y dibujos), parte de las cuales estaban dedicadas a temas arqueológicos como arquitectura, necrópolis y ajuares funerarios donde se encontraron cerámica y textiles. Parece que mandó realizar excavaciones, pues en una lámina está representado el cadáver de un jefe indígena de importancia con su vestimenta, acompañado de su ajuar. También se dibujaron objetos precolombinos sin contextualización estratigráfica.

2. Miguel Feijoo nació en Arequipa, en el virreinato del Perú. Ejerció varios cargos, entre ellos corregidor de Trujillo y contador mayor del tribunal y audiencia de cuentas del Perú. Escribió Relación descriptiva de la ciudad y provincia de Trujillo del Perú con noticias exactas de su estado político. ${ }^{45}$ Realizó la primera excavación estratigráfica documentada, que se incluyó en el Códice Trujillo de Martínez Compañón.

\section{Intelectuales que escribieron a título propio}

1. José Eusebio de Llano Zapata nació en Lima en 1721. Se educó en el seno de una pudiente y prestigiosa familia limeña. Escribió sobre flora, fauna, geología, historia, el terremoto de 1746 y otros temas. Salió de Lima para no volver jamás en 1751. Antes de ir a Europa, viajó por cuatro años a Chile, Buenos Aires, Montevideo y Río de Janeiro. En estos lugares recolectó información de campo y material bibliográfico. En su afán por publicar sus Memorias histórico, físicas, apologéticas de la América Meridional, viajó a Cádiz en 1755 para obtener autorización, pero no la consiguió. Sin embargo, durante su estadía en la metrópoli publicó otros libros. Murió en 1780. El pensamiento de Llano Zapata ha sido considerado como el de un ilustrado católico, un erudito que procuró conciliar su convicción religiosa con el razonamiento crítico y el método experimental. Su pensamiento coincidía con la de los novatores, término con el que se identificó en España al grupo de intelectuales cuya apertura a las novedades de la ciencia a fines del siglo XVII no estuvo reñida con la defensa de su fe católica. ${ }^{46}$ En conclusión, la arqueología precientífica practicada por Llano Zapata radicaba principalmente en la observación y la tradición oral.

\footnotetext{
45 AGI, MP-Libros_Manuscritos, 18, 06-12-1761. Relación descriptiva de la ciudad y provincia de Trujillo del Perú, con noticias exactas de su estado político, según el real orden dirigido al Excelentísimo Señor Virrey Conde de Superunda. Peralta Ruiz; Epítome cronológico, p. 25. Este manuscrito finalmente se publicó en Madrid en 1763, pero sin las ilustraciones del manuscrito.

46 Peralta Ruiz, Epítome, pp. 36-38.
} 
Relación de arqueólogos precientíficos del siglo XVIII que describieron antigüedades en zona peruana

\begin{tabular}{|lllll|}
\hline Año & \multicolumn{1}{c}{ Función } & \multicolumn{1}{c}{ Autor } & \multicolumn{1}{c}{$\begin{array}{c}\text { Lugar } \\
\text { arqueológico }\end{array}$} & \multicolumn{1}{c|}{ Región } \\
\hline 1710 & Viajero & Louis de Feuillée & $\begin{array}{l}\text { Pachacamac } \\
\text { Pachacamac }\end{array}$ & \multicolumn{1}{c}{ Costa central del Perú } \\
1716 & Viajero & Amédé Fentral del Perú \\
1762 & Funcionario & Miguel Feijoo & Moche & Costa norte del Perú \\
1778 & Funcionario & Ramón Arechaga & Sacsayhuamán & Sierra del Perú. Cuzco \\
1779 & Viajero & Hipólito Ruiz y Pavón & Pachacamac & Costa central del Perú \\
1780 & Independiente & José Eusebio Llano & Sacsayhuamán & Sierra del Perú. Cuzco \\
& & Zapata & & \\
1782 & Funcionario & Baltasar Jaime & Moche & Costa norte del Perú \\
& religioso & Martínez Compañón & & \\
1787 & Independiente & José Hipólito Unanue & Tiahuanaco & Altiplano \\
1790 & Viajero & Antonio Pineda & Pachacamac & Costa central del Perú \\
1793 & Viajero & Tadeo Haenke & Sacsayhuamán & Sierra del Perú. Cuzco \\
\hline
\end{tabular}

\section{Tipos de trabajos realizados por los arqueólogos} precientíficos que describieron antigüedades

del Perú en el siglo XVIII

\section{A. Visitas y colecciones}

\section{1. "Las antiguallas" y el Códice de Jaime Baltasar Martínez Compañón}

El obispo Martínez Compañón envió a la metrópoli 24 cajones con antigüedades y otros productos de la diócesis de Trujillo. Estos objetos viajaron desde la capital del virreinato del Perú embarcándose bajo partida de registro en la fragata de libre comercio La Rosa, que zarpó del puerto del Callao rumbo a Cádiz el 28 de febrero de 1779. ${ }^{47}$ Este envío respondía al pedido realizado por Real Cédula de Instrucción del 29 de octubre de 1776, en que se encargaba a las autoridades eclesiásticas y civiles que se procediese a recoger las curiosidades y antigüedades que hubiera para ser enviadas al Real Gabinete de Historia Natural de Madrid.

47 AGI, Lima 683, núm. 68. 2 folios. 28 -02- 1779. Carta nª 68 del Virrey Croix a Antonio Porlier, secretario de Estado de Gracia, justicia y materias eclesiásticas de Indias. Remite representación con su respectivo índice que le ha dirigido el obispo de Trujillo Baltasar Jaime Compañón, y comunica de los 24 cajones relacionados. 
Durante la visita a su obispado se elaboraron 1411 láminas sobre diferentes temas: planos de ciudades, trajes, edificios, costumbres, bailes, instrumentos musicales, flora, fauna, aves, peces y modos de pesca de su diócesis. De las acuarelas, 108 representan antigüedades de arquitectura, cerámica, tejidos y otros objetos precolombinos que encontró. Esos dibujos son anónimos, lo cual se debe a que fueron hechos por artesanos indígenas o mestizos. La similitud en el trazo hace pensar en la existencia de un posible grupo artesanal de dibujantes indígenas o mestizos en Trujillo a la llegada del obispo. Llama la atención la precisión de los trabajos y la utilización de la escala en varas castellanas. La caligrafía está muy bien lograda.

Las láminas fueron realizadas y terminadas en la diócesis de Trujillo en 1788 y conservadas por Martínez Compañón hasta su muerte en 1797. En su testamento solicitó que se recogiesen las láminas que tenía su albacea Fausto Sodupe para remitirlas a España, al rey Carlos IV. ${ }^{48}$ Las acuarelas y seis cajones con antigüedades (objetos recolectados), después de haber sido examinados por el cabildo secular, el cabildo eclesiástico, la real hacienda y el virrey, fueron enviados a Madrid en 1803. ${ }^{49}$ Pero tal parece que los objetos de las láminas nunca llegaron, por la poca correspondencia con los que se encuentran en el Museo de América, repositorio final de las colecciones americanas del siglo XVIII. Por lo que se supone, se quedaron en algún lugar del continente americano. ${ }^{50}$ Los objetos que sí se conservan son los enviados en 1790 de la diócesis trujillana a España. En cuanto a las acuarelas, se encontraron sin texto alguno. Algunos consideran que el texto se perdió, que no se escribió, o que está en algún archivo español o de Bogotá. ${ }^{51}$

Una de las razones que daba Martínez Compañón para mandar hacer las láminas fue que sirviese de ayuda en el cotejo con los objetos enviados. Una prueba de la fidelidad de lo representado en los dibujos:

cotejadas dichas piezas y estampas, se vean la conformidad y perfecta semejanza entre unas y otras, y por ellas pueda conjeturarse, o creerse, y comprenderse ser igual la correspondencia de las estampas de los ocho restantes tomos y sus originales, por haberse formado con ellos a la vista y a mi presencia. ${ }^{52}$

\footnotetext{
48 Arbeiza, Martínez Compañón, p. 22.

49 Alcina Franch, Arqueólogos, p. 184. Domínguez, Manuscritos, p. 1935.

50 Cabello, Coleccionismo, p. 163.

51 Vargas Ugarte, Don Baltasar, p. 442.

52 AGI, Indiferente general, núm. 1545. Expedientes de remisiones de maderas, plantas, semillas y otras producciones de América, 1779-1791.
} 
El volumen IX sobre antigüedades de Trujillo del Perú fue el último en escribirse, pero el obispo no pudo terminar su trabajo porque le sobrevino la muerte y no logró remitir ni mandar dibujar las piezas de metal, madera y piedra que había indicado en su carta:

Otro cajón tengo también pronto de piezas de oro, plata, tumbaga, cobre, madre de perla, o concha de nácar, hueso, piedra, madera, pita y algodón, hechas por los indios del mismo tiempo y obispados, y extraídas de sus huacas y sepulcros. ${ }^{53}$

\section{Relación descriptiva de la ciudad y provincia de Trujillo del Perú con noticias exactas de su estado político, de Miguel Feijoo}

En 1760 Feijoo escribió este libro por orden del virrey José Antonio Manso de Velasco, conde de Superunda, cuando era corregidor de la ciudad de Trujillo, en la costa norte del Virreinato del Perú. Feijoo tuvo un claro interés por las antigüedades precolombinas.

\section{B. Planos, mapas y dibujos}

\section{La primera expresión iconográfica más temprana} de la arqueología pre-científica en el Perú

En la Relación descriptiva de la ciudad y provincia de Trujillo del Perú con noticias exactas de su estado político, redactada en 1760 por Miguel Feijoo, se encuentra un mapa con algunas construcciones precolombinas de la costa norte peruana, como ciudadelas, grandes canales y tumbas. Se puede considerar una de las primeras expresiones gráficas más tempranas de la arqueología precientífica en el Perú. El mapa es una de las tres ilustraciones de su obra y lleva por título Descripción del valle de Chimor, donde se ve el río Moche. También localizó varios sitios precolombinos que denominó "casas arruinadas del Reino Chimú", tumbas como la "Guaca Toledo" y varios canales de irrigación antiguos, como la "acequia Mochica" (Vicanchao y Moro), que proporcionaban agua a las famosas construcciones chimúes de Chan Chan. Este plano está hecho a pluma y sus dimensiones son 440 x $340 \mathrm{~mm} .^{54}$

\footnotetext{
53 AGI, Indiferente 1545. Carta de Baltasar Jaime, arzobispo de Santa Fe, a D. Antonio de Porlier, secretario de Estado y del Despacho Universal de Gracia y Justicia de España y de las Indias. Cartagena, el 13 de diciembre de 1790.

54 AGI, Libros Manuscritos: 18. 95 folios, 3 mapas y 3 ilustraciones.
} 


\section{Figura1}

Mapa del valle de Chimo y planisférica de la ciudad de Trujillo del Perú

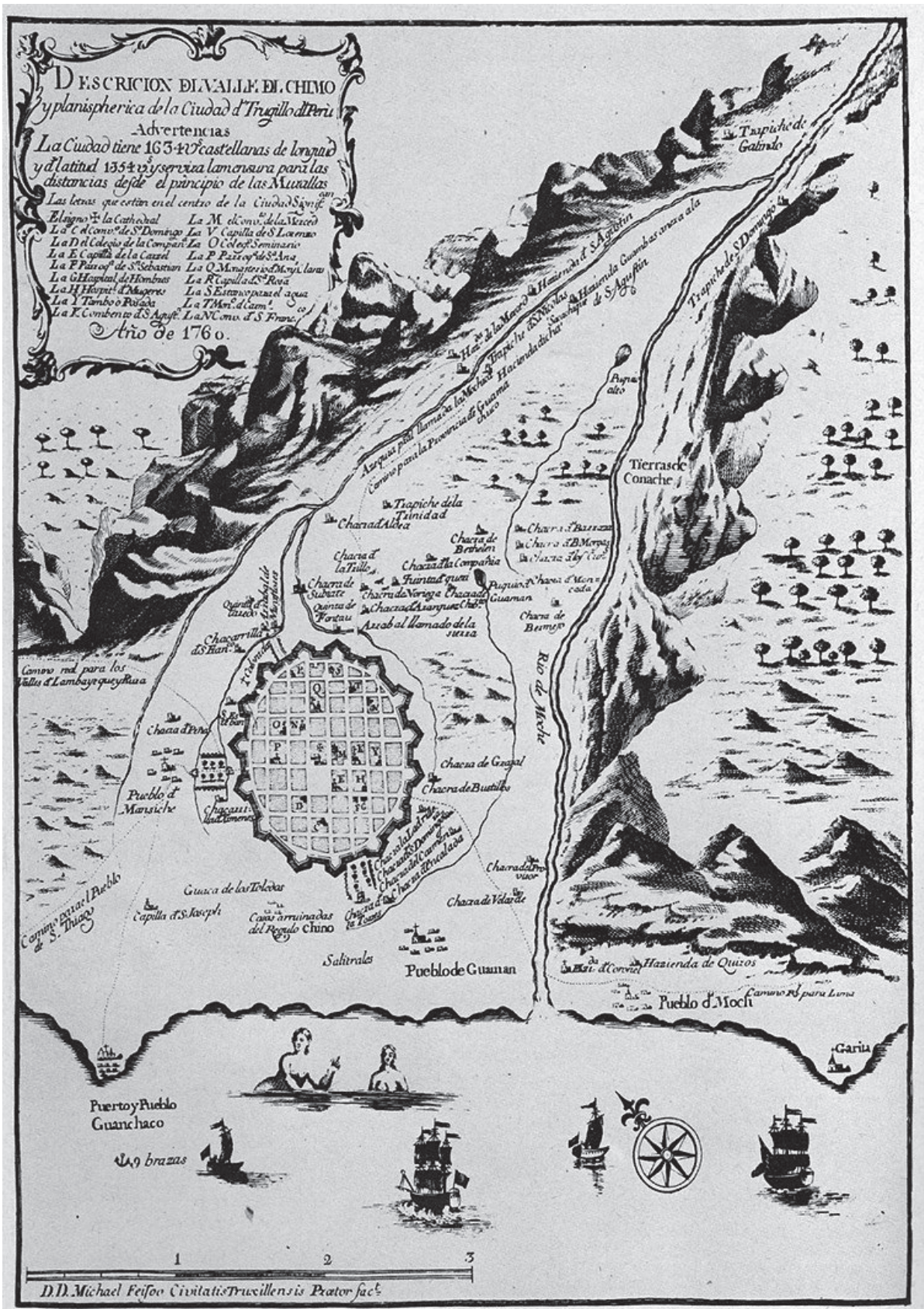

Fuente: Feijoo. Relación 


\section{La segunda expresión iconográfica más temprana de la arqueología peruana}

El más importante aporte a la arqueología peruana del manuscrito Epítome cronológico o Idea general del Perú de Llano Zapata sería la inclusión de una lámina del sitio arqueológico de Sacsayhuamán en el Cuzco. Esta lámina constituye la segunda expresión iconográfica más temprana de la arqueología peruana, después de la de Miguel Feijoo de Sosa en su Relación descriptiva de la ciudad y provincia de Trujillo del Perú. ${ }^{55}$

\section{Figura 2}

Vista del cerro y fortaleza fabricada

por los Incas del Perú en la ciudad del Cuzco

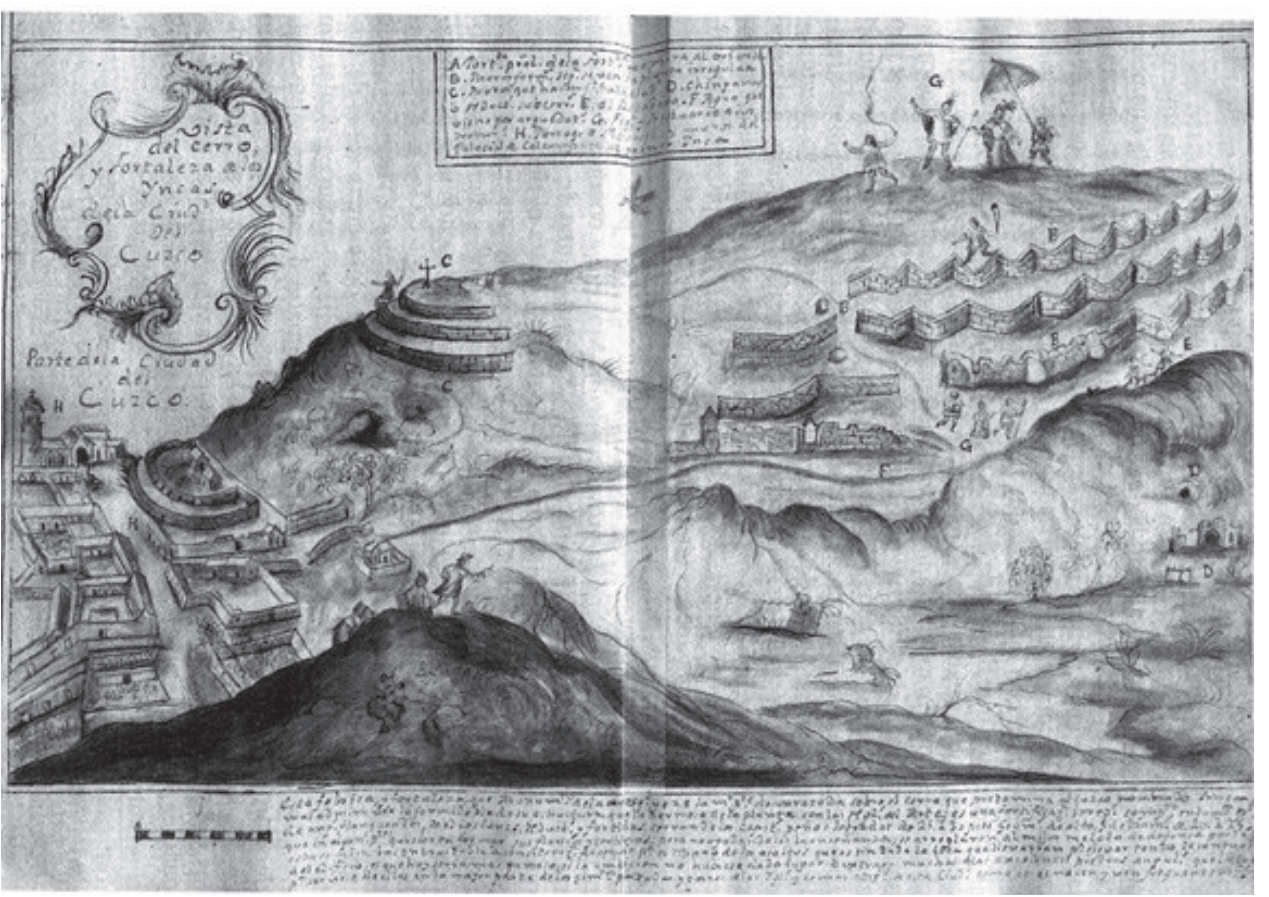

Fuente: Llano Zapata, Epitome Cronológico o idea general del Perú de 1776, ff.18 y 19.

Se trata de un dibujo a escala de la fortaleza o castillo inca de Sacsayhuamán en el Cuzco. La lámina se titula Vista del cerro y fortaleza de los Incas de la ciudad del Cuzco. Tiene dos leyendas, una genérica y la otra especifica. Se trata de una lámina en blanco y negro. No indica autor, pero es similar a otra en el Archivo General de Indias con la signatura AGI/MP/

${ }_{55} \mid$ Peralta Ruiz, Epítome, p. 25. 
MP- Perú_ Chile, 220, la cual está hecha a colores. Se ha atribuido al sargento mayor de infantería Ramón de Arechaga y Calvo, 1778.

En esta lámina de la fortaleza de Sacsayhumán se muestran dos leyendas. La primera indica detalles genéricos del sitio arqueológico:

Esta fortaleza que monumento de la corte que yo sé la mayor parte desbaratada sobre el cerro que predomina el Cuzco que nombrado Senca admira por lo formidable de su estructura, que lo hermoso con la planta de las reglas del arte; es una fortificación irregular compuesta en la mayor parte de ángulos flanqueados, medias lunas, reductos y furtidas cerrando los capiteles peñas labradas de 25 a 30 pies geométricos de alto, y de diámetro de 20 a 24 que en algunas partes quisieron formar sus flancos y cortinas.

La segunda leyenda explica las partes de esta construcción siguiendo las letras del alfabeto que aparecen en el dibujo.

\section{Cortes estratigráficos}

\section{Baltasar Martínez Compañón y la representación gráfica del primer corte estratigráfico "arqueológico" realizada por Miguel Feijoo en la costa norte del Perú (1765)}

A Feijoo se le atribuiría la primera excavación estratigráfica que se hizo en América, veinte años antes que la realizada por Thomas Jefferson en Estados Unidos. Tuvo lugar en la llamada Huaca de Tantalluc entre 1763 y $1765 .{ }^{56}$ Esa excavación la realizó después de redactado el manuscrito de la Relación descriptiva de la ciudad y provincia de Trujillo del Perú con noticias exactas de su estado político. Cedió los dibujos del corte estratigráfico al obispo de Trujillo Martínez Compañón, quien los incluyó en su obra, en el volumen IX de la colección, en 1776.

Así pues, una de las láminas de la obra de Martínez Compañón es el corte estratigráfico realizado por Feijoo en el cerro de Tantalluc en la provincia de Cajamarca. Corresponde al folio número 9, que lleva por título "Huaca situada en el cerro Tantalluc de la provincia de Cajamarca que se descubrió y excavó en el año pasado de 1765".

El dibujo representa una pirámide a modo de montaña, en cuyo interior se encontró un entierro con un rico ajuar funerario. El corte estratigráfico está representado en las faldas de la huaca, donde se observan

\footnotetext{
${ }_{56}$ Alcina, Arqueólogos, pp. 172-173.
} 
claramente los estratos cuyas características se definen con explicaciones precisas del material extraído.

El gráfico tiene escala en varas (25 varas). El pozo presenta un ancho de 3.34 metros según escala. ${ }^{57}$ Martínez Compañón señala que Tantalluc era una montaña que, para depositar las ofrendas, se tuvo que horadar, y después fue sellada y cubierta con tierra y cascajo. No se ha localizado este lugar, a pesar de los intentos de Jiménez de la Espada (1896) y Udo Oberem (1953).

No se trataría de una ofrenda escondida, sino de parte del ajuar funerario de un personaje que no sabemos si fue encontrado. Así, no sería un monte lo que se excavó, sino un túmulo funerario. Hoy se sabe, por la recurrencia de estos entierros, que eran pirámides hechas de adobe, y que con la erosión y el paso del tiempo semejaban prominencias naturales. La Huaca Tantalluc podría haber sido una pirámide de adobe, según se indica en una de las leyendas del dibujo: "Las paredes interiores que tenía de mampostería por sus cuatro lienzos".

Así pues, la peculiaridad de la excavación realizada por Feijoo fue que se dibujó la estratigrafía. La parte exterior de la excavación se describe de la siguiente manera:

A: Cerro nombrado Tantalluc visto por el Este.

B: Loma unida a él.

C: Cerro pequeño artificial de tierra que ocultaba la boca de la huaca.

D: El mismo cerro de Tantalluc visto por el Norte.

La estratigrafía propiamente dicha de la huaca esta descrita en un dibujo transversal y las capas se numeraron en forma descendente.

\begin{tabular}{|ll|}
\hline \multicolumn{1}{|c}{ Según Feijoo } & \multicolumn{1}{c|}{ Interpretación } \\
\hline E: La loma partida o excavada. & $\begin{array}{l}\text { Capa E: Vista transversal de la } \\
\text { estratigrafía. }\end{array}$ \\
excavado. & $\begin{array}{l}\text { Capa F: Retirada de tierra y cascajo de } \\
\text { aproximadamente } 5.80 \text { metros de alto } \\
\text { según Oberem, }{ }^{*} \text { al convertir las varas a } \\
\text { metros. }\end{array}$ \\
G: Cañón de dicha huaca partido o & Capa G: Calicata en sí, con un anchura \\
dividido por la mitad con su largo y & según escala de 3.35 m. \\
ancho, y las paredes interiores que tenía & La mampostería indicaría que era una \\
de mampostería por sus cuatro lienzos. & construcción, no un cerro. \\
H: Piedra que cubría dicho cañón. & Capa H: adobes grandes dispuestos en \\
& horizontal. \\
& \\
$57 \mid$ Alcina, Arqueólogos, p. 174. &
\end{tabular}


I: Hueco entre dicha piedra y la capa de tierra que sigue.

$\mathrm{J}$ : Capa de tierra negra.

$\mathrm{K}$ : Idem de blanca.

L: Capa de carbón.

M: Idem de tierra común.

$\mathrm{N}$ : Idem de ceniza.

O: Idem de greda amarilla.

P: Piedra.

Q: Hueco, y en su fondo una piedra, y sobre ella muchas piezas de diversas figuras de oro y algunas de cobre.
Capa I: Impronta del adobe en tierra común y corriente.

Capa J: Tipo de tierra negra.

Capa K: Tipo de tierra blanca.

Capa L: Restos de posible ritual funerario.

Capa M: Tierra común.

Capa N: Ceniza, que serían restos de posible ritual funerario.

Capa O: Yeso amarillo.

Capa P: Piedra. La base del pozo se halla una cámara que estaba cerrada con una gran piedra plana.

Capa Q: Ajuar funerario: figuras de oro y cobre.

* Oberem, La obra, p. 254.

\section{Figura 3}

Huaca situada en el cerro nombrado Tantalluc de la provincia de Taxamarca

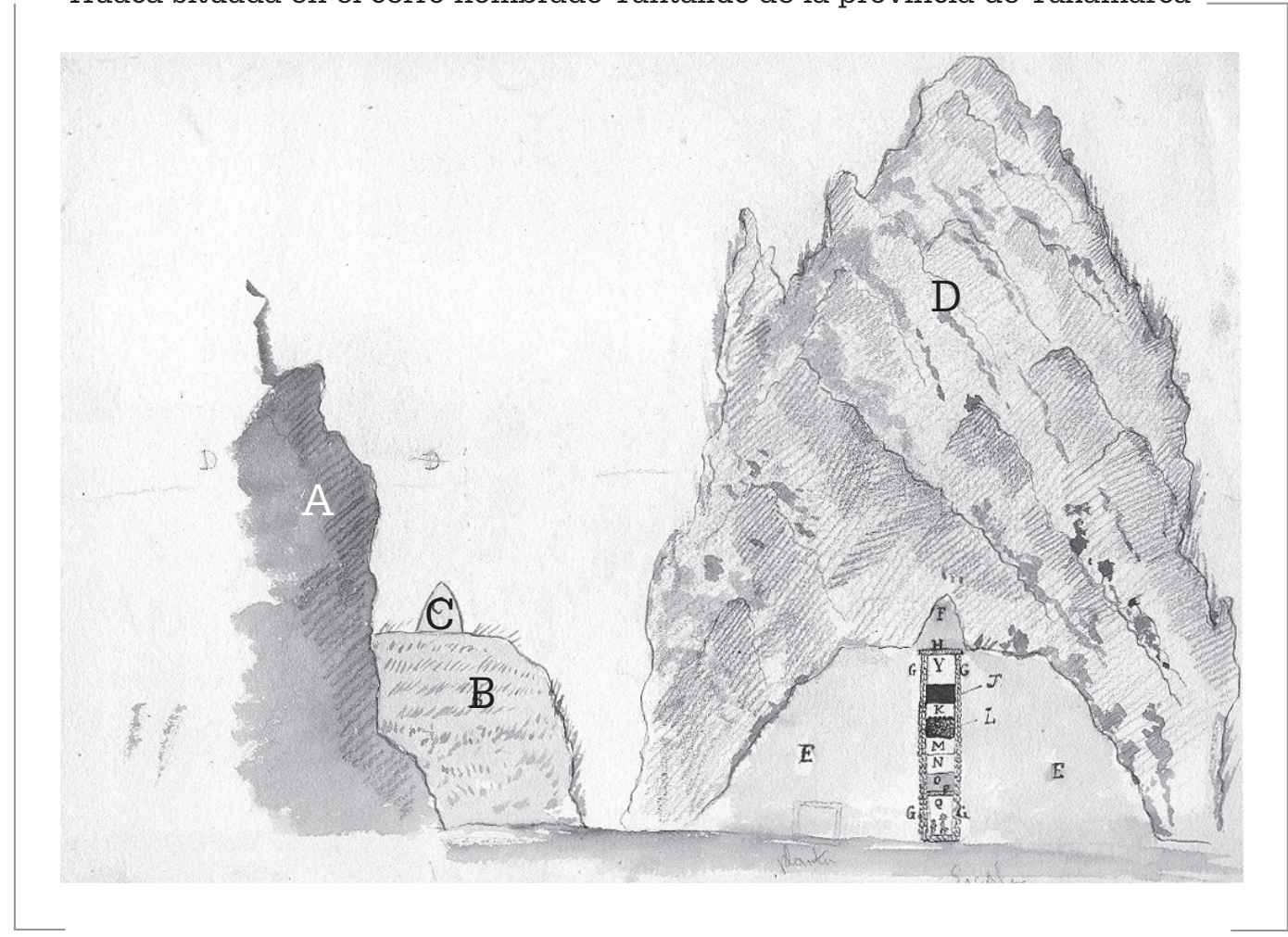

Fuente: ABGH, CSIC, Marcos Jiménez de la Espada, ca. 1870. 


\section{Figura 4}

Dibujo del primer corte estratigráfico en la Huaca Tantalluc en 1765

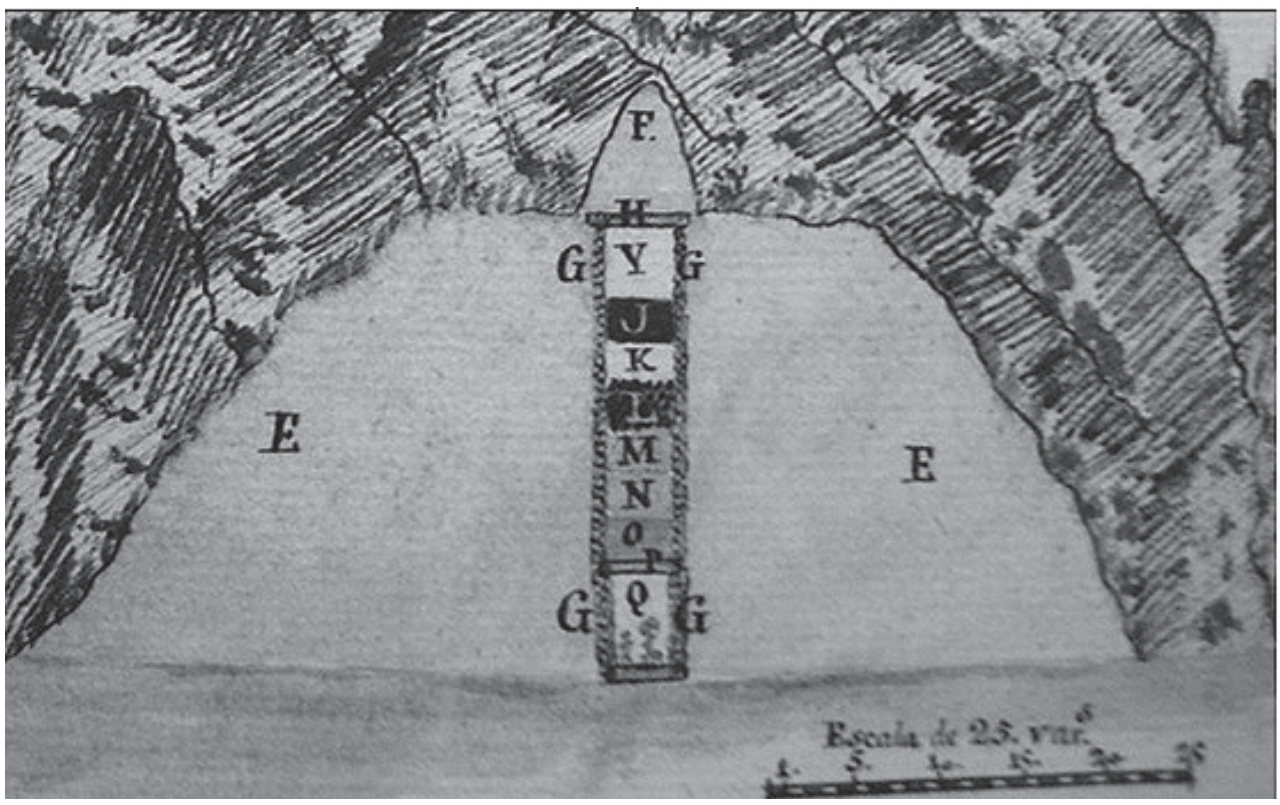

Fuente: Martínez Compañón, Trujillo del Perú.

La excavación de Feijoo permitió reconocer niveles diferentes en la zanja tanto de material edafológico como antropológico.

\section{Libros}

\section{José Eusebio de Llano Zapata}

\section{y su lucha por publicar una historia americana}

Llano Zapata fue autor de trabajos sobre antigüedades en el virreinato del Perú, el primero de los cuales (Memorias histórico, físicas, critico, apologéticas de la América Meridional) lo escribió en Cádiz en 1757. La parte histórica la terminó, pero para elaborar la parte física pidió ayuda gubernamental. ${ }^{58}$ Esta obra recibió el apoyo de intelectuales españoles como Alonso María Acevedo, en nombre de la Real Academia de la Historia, ${ }^{59}$

58 AHN, Diversos, 29, Doc.9.07-07-1780. Carta a D. José Gálvez pidiendo protección y ayuda para escribir sus Memorias histórico-físicas de la América Meridional. Lugar de emisión Cádiz.

59 AHN, Diversos, 29, Doc.11. 03.04.1766. Carta de D. Alonso María Acevedo, en nombre de la Real Academia de la Historia, a D. José Eusebio de Llano Zapata. Madrid. 
pero la férrea censura y el celo del Consejo de Indias no le permitió editarlo. ${ }^{60}$ Muy pocos fueron los americanos que escribieron historias naturales y civiles de sus lugares de origen en el siglo XVIII. ${ }^{61}$

Se publicó parte de la obra muchos años después, en 1904, gracias a las gestiones del director de la Biblioteca Nacional del Perú, Ricardo Palma.

\section{Llano Zapata observó que el capítulo}

de inscripciones, medallas, edificios, templos, antigüedades y monumentos hubiera preferido no desarrollarlo porque lo consideraba la piedra en que han tropezado todos o los más de nuestros cronistas e historiadores [... por] la falta de indagación o su mucha credulidad.

Con estas palabras pone en tela de juicio el estudio de las antigüedades en razón de la falta de rigor del método histórico y lo poco confiable de la información.

De esta manera, tal como él mismo lo indicó, cometió el error de recurrir a la terminología y los métodos propios para el estudio de las antigüedades europeas usados a mediados del siglo XVIII en España, como la epigrafía y la numismática, siendo que las culturas precolombinas peruanas no tuvieron escritura ni moneda. También buscó conectar la historia peruana con la Biblia al buscar en algunos ideogramas pistas de la llegada de algún hijo de Noé o de algún apóstol (idea recurrente en la anticuaria europea ilustrada del siglo XVIII). ${ }^{62}$

Una metodología para el estudio de las antigüedades en el Perú fue la tradición oral, es decir, el relato hablado intergeneracional, ejercicio cotidiano entre los indígenas: "es asentada tradición y antigüedad heredada

60 Torre Revello, Prohibiciones, pp. 17-47. La Real Academia de Historia no otorgó ninguna licencia para imprimir una historia general del continente, a excepción del primer tomo de las Memorias histórico-físicas critico-apologéticas de Llano Zapata, que aunque obtuvo el informe favorable de los académicos finalmente no se editó por oponerse a ello el Consejo de Indias.

61 Peralta Ruiz, Epítome, pp. 36-54. Esta afirmación queda respaldada por los investigadores dedicados a la historia de la historiografía, quienes coinciden en destacar la falta de una historia general y civil del Perú, escrita en el siglo XVIII.

62 Trigger, Historia del pensamiento, p. 76: "Los anticuarios europeos habían aprendido desde el siglo XV a describir y a clasificar monumentos y artefactos a excavar y registrar los hallazgos, y a usar varios métodos de datación, incluida la estratigrafía, al estimar la edad de algunos hallazgos". 
de todos los indios de Collana, de Lama y de sus contornos". ${ }^{63}$ Recurrió también a noticias orales citadas en otros libros. Así, dio importancia a la oralidad en el análisis de la anticuaria peruana.

Llano Zapata se lamentaba que sobre las antigüedades peruanas existía más información exagerada y abultada que real. "Desnudo de pasión y siendo imparcial", trató de describirlas en su obra a mediados del siglo XVIII. Para lo que no observó in situ, recurrió a fuentes primarias directas: las crónicas. Describió los monumentos precolombinos diseminados desde Lima hasta Buenos Aires, que en aquel entonces aún pertenecían al virreinato del Perú. Sólo puso en su obra lo que observó en su recorrido y lo que consideró que tenía autoridad suficiente por tradición y longevidad. Asimismo, reconoció "la destreza de los artífices que las levantaron y [...] la tradición de aquellos tiempos que hasta los nuestros se propaga aún a pesar de las edades, la ignorancia y el desprecio". ${ }^{64}$

En el Cuzco, los monumentos de piedra descritos fueron el castillo de Sacsayhuamán y el templo de Koricancha. Describió los grandes bloques de piedra, pero no pudo explicar cómo se labraron y transportaron. En la actualidad esta descripción sirve para complementar la información, comparar y ver su grado de conservación. Por ejemplo, partes del castillo de Sacsayhuamán tal como está descrito en sus Memorias ya no existen, como los alojamientos subterráneos y la fuente de agua.

En el Collao, colindante con el lago Titicaca, mencionó los sitios arqueológicos de Pucara, Kalassassaya y Tiahuanaco. Llano Zapata destaca el trabajo de las piedras, bien labradas y sólidas. Se percató que aquellos monumentos eran más antiguos que los restos encontrados en el Cuzco. En este caso, los indígenas que construyeron estos monumentos desaparecieron mucho tiempo antes de que llegaran los españoles. Averiguó que no existía tradición oral sobre los constructores tiahuanaquenses.

Este arqueólogo precientífico indicó que muchos edificios precolombinos fueron utilizados como cantera para la construcción de pueblos y ciudades y otra parte "yace [...] por los suelos, siendo afrentosa injuria de nuestro desprecio e ignorancia y no del tiempo y sus mudanzas". ${ }^{65}$

En 1776 Llano Zapata escribió Epítome cronológico o Idea general del Perú, un relato literario, histórico y político del virreinato que abarcaba desde el origen de los incas hasta el año de 1776, cuando gobernaba el virrey Manuel de Guirior, conde de Guirior. En esa obra se daba importancia a las antigüedades prehispánicas, ya como curiosidades, ya como

\begin{tabular}{l|l}
63 & Llano Zapata, Memorias, p. 380. \\
64 & Llano Zapata, Memorias, p. 376. \\
65 & Llano Zapata, Memorias, pp. 387-388.
\end{tabular} 
riquezas culturales que ennoblecían, pues para Llano Zapata el pasado incaico daba prestigio al virreinato peruano. Se encuentra en esta obra una minuciosa descripción cualitativa y cuantitativa de lo observado. Así, midió algunos monumentos precolombinos, costumbre muy propia entre los intelectuales de la época. Su viaje siguió un itinerario de peregrinaje frecuentado por los ilustrados de la época por las principales antigüedades monumentales del virreinato del Perú, una ruta que compendia Cuzco, Tiahuanaco y Paramonga. Las observaciones y reflexiones sobre los sitios visitados están en Epítome cronológico o Idea general del Perú:

Por las ruinas que hoy se ven de la fortaleza de Paramonga se infiere su primera grandeza aun siendo toda de tierra, pero tan sólida y unida que puede competir con la más fuerte roca; los pedazos de pintura que se manifiestan en las paredes de las viviendas que se comprendían dentro del último cerco de los tres de que se componía la fortificación, aun con estar expuesta al sol y a la lluvia, se mantiene con más viveza que la moderna. ${ }^{66}$

En cuanto a los monumentos precolombinos en la ciudad del Cuzco, menciona que "no hay calle que no tenga señales bastantes de la grandeza de estos edificios, ya del Templo del Sol, Casas de las Vírgenes, ya de los Palacios de los Incas", y se queja del descuido y hurto de las piedras labradas incas, utilizadas como cantería, y de que no se apreciara su belleza y no se conservaran para deleite de las generaciones venideras: "Siendo cosa lastimosa que el descuido y desbarato haya perdido a la perpetuidad de los siglos la perfección en que [...] la verían los primeros españoles como que en éstos hubiese faltado la curiosidad de indagar el arte". ${ }^{67}$

\section{Conclusiones}

A finales del siglo XVII se desarrollaron cambios en el campo filosófico, político y cultural en Europa y en la península ibérica que hicieron que el siglo XVIII empezara con nuevas ideas ilustradas, de las que eran particípes los monarcas borbónicos. La Ilustración dio paso a nuevas instituciones, que convivieron con las antiguas, ya anacrónicas, que el despotismo ilustrado español no pudo ni se atrevió a eliminar, por lo cual surgieron contradicciones en su gestión.

\footnotetext{
66 Llano Zapata, Memorias, p. 103.

67 Llano Zapata, Memorias, p. 103.
} 
Así, viajeros enviados por la Corona y funcionarios, generalmente europeos, escribieron sobre las antigüedades y recolectaron curiosidades del área andina, mientras que los mestizos y criollos apenas lo hicieron. Esta aparente pérdida de interés estaba ligada a la severa política de Estado de la Corona española a través de la férrea censura y el celo del Consejo de Indias en el control de las publicaciones indianas. De tal manera, muy pocos fueron los americanos que escribieron historias naturales y civiles de sus lugares de origen en el siglo XVIII.

Los arqueólogos precientíficos de la Ilustración excavaban para extraer objetos y exhibirlos en colecciones, aunque a veces algunos de ellos "leían" los cortes estratigráficos, uno de los cuales quedó documentado (fue el caso de Miguel Feijoo). Estos procedimientos permitían conocer de alguna forma las culturas precolombinas.

Lo más destacado en cuanto a arqueología precientífica de ese siglo fue la labor de dos funcionarios en el corregimiento y obispado de Trujillo, en la costa norte del virreinato del Perú. Uno era criollo, el corregidor Feijoo, quien hizo una excavación estratigráfica en 1765 que fue dibujada y enviada a la metrópoli junto con otras 108 láminas sobre antigüedades, al Real Gabinete de Historia Natural, por el obispo Martínez Compañón. La excavación de Feijoo permitió reconocer material edafológico y antropológico en los diferentes niveles del corte estratigráfico.

Paulatinamente, a diferencia de los siglos anteriores, cuando las antigüedades se extraían por razones económicas y se consideraban "antiguallas" y curiosidades, se comenzó a buscarlas con fines cognitivos, lo que se convirtió en actividad de moda y bien vista entre la intelectualidad de la época.

\section{Siglas}

AGI Archivo General de Indias

ABGH, CSIC Archivo de la Biglioteca General de Humanidades del Consejo Superior de Investigaciones Científicas

\section{Bibliografía.}

Alcina Franch, José

Antropólogos y disidentes. Una tradición tenue, Palma de Mallorca, Les edicions de Bitzoc, 1999.

Alcina Franch, José

Arqueólogos o anticuarios: historia antigua de la arqueología en la

América española, Barcelona, Ediciones del Serbal, 1995.

Almagro-Gorbea, Martín 
"La arqueología en la política cultural de la Corona de España en el siglo XVIII", en De Pompeya al Nuevo Mundo. La Corona española y la arqueología en el siglo XVIII, Madrid, Real Academia de la Historia, Patrimonio Nacional, 2012.

Alonso Rodríguez, María del Carmen

"Documentos para el estudio de las excavaciones de Herculano, Pompeya y Estabia en el siglo xVIII bajo el patrocinio de Carlos III", Bajo la cólera del Vesubio. Testimonios de Pompeya y Herculano en la época de Carlos III, Valencia, Generalitat Valenciana, Conselleria de Cultura, Educació i Esport, 2004, pp. 49-82.

Arbeiza, Teófilo de

Martínez Compañón, Diputación Foral de Navarra, Pamplona, s/f.

Bertham, Lee

Libros de Cabildo de Lima. Libro Noveno, Años 1579-1583, Lima, Consejo Provincial de Lima, Impresores Torres Aguirre Sanmarti, 1937.

Cabello Carro, María Paz

"La arqueología ilustrada en el nuevo mundo", De Pompeya al Nuevo Mundo. La Corona española y la arqueología en el siglo XVIII, Madrid, Real Academia de la Historia, Patrimonio Nacional, 2012, pp. 255-279.

Cabello Carro, María Paz

"La formación de las colecciones americanas en España: evolución de los criterios", Anales del Museo de América, núm. 9, 2001, pp. 303318.

Cabello Carro, María Paz

Coleccionismo americano indígena en la España del siglo XVIII, Madrid, Ediciones de la Cultura Hispánica, AECI, 1989.

Cangas, Gregorio

"Descripción dialogada de los pueblos y costumbres del Perú", Simposio sobre la causa, 1960, pp. 245-335.

Casas, Bartolomé de las

Los tesoros del Perú, Madrid, Instituto Gonzalo Fernández de Oviedo, 1958.

Cieza de León, Pedro

La Crónica del Perú (1553), edición de Manuel Ballesteros, Madrid, Historia 16, 1984.

Domínguez Bordona, Jesús

"Manuscritos de América", Catálogo de la Biblioteca de Palacio, t. IX, Madrid, Gráficas Reunidas, 1934.

Feijoo, Miguel

Relación descriptiva de la Ciudad y Provincia de Trujillo del Perú (1763), Madrid, Imprenta Real y Supremo Consejo de Indias (facsimi- 
lar: edición conmemorativa, Lima, fondo del Libro del Banco Industrial del Perú, 1984).

Fernández Murga, Félix

Carlos III y el descubrimiento de Herculano, Pompeya y Estabia, Salamanca, Ediciones Universidad de Salamanca, 1989.

Frézier, Amédée François

Relación del viaje por el Mar del Sur, Caracas, Biblioteca Ayacucho, 1982.

Glyn, Daniel

Historia de la arqueología: de los anticuarios a V. Gordon Childe, Madrid, Alianza, 1981.

González, José Luis

"La crónica y su concepto de la cosmovisión andina: indios, dioses

y demonios", La persecución del Demonio: crónica de los primeros agustinos en el norte del Perú (1560). Fray Juan de San Pedro, Málaga, Algazara, 1992, pp. 7-37.

Juan, Jorge y Antonio de Ulloa

Relación histórica del viaje a la América Meridional, t. I, Madrid, Fundación Universitaria Española, 1978.

Llano Zapata, José Eugenio

Memorias histórico, físicas, crítico, apologéticas de la América Meridional (1757), Lima, Imprenta y librería de San Pedro, 1904.

Martínez Compañón, Baltasar, Trujillo del Perú: vida y costumbres, Madrid, Agencia Española de Cooperación Internacional, Ministerio de Asuntos Exteriores, 1985.

Nava Rodríguez, María Teresa

Reformismo ilustrado y americanismo: la Real Academia de la Historia, 1735-1792, Madrid, Universidad Complutense de Madrid, 1989.

Oberem, Udo

La obra del obispo don Baltasar Jaime Martínez Compañón como fuente para la arqueología del Perú septentrional, Madrid, Instituto Gonzalo Fernández de Oviedo, 1954.

Peralta Ruiz, Víctor

Epítome cronológico o Idea general del Perú. Crónico general de 1776, Madrid, Fundación Mapfre, 2005.

Renfrew, Colin

Arqueología: teorías, métodos y práctica, Torrejón de Ardoz, Akal, 1998.

Rivero y Ustariz, Mariano Eduardo de y Juan Diego Tschudi

Antigüedades peruanas, Viena, Imprenta Imperial de la Corte y del Estado, 1851.

Serna Arnaiz, Mercedes 
"Censura e Inquisición en las crónicas de Indias. De sus adversidades

e infortunios", en Tierras prometidas, de la colonia a la independencia, Sardañola del Vallés, Universidad Autónoma de Barcelona, 2011, pp. 347-360.

Torre Revello, José, "Prohibiciones y licencias para imprimir libros referentes a América, 1737-1807", Boletín del Instituto de Investigaciones Históricas, Buenos Aires, 1932, núm. 51-52, pp. 17-47.

Trigger, Bruce

Historia del pensamiento arqueológico, Barcelona, Crítica, 1992.

Vargas Ugarte, Rubén

"Don Baltasar Jaime Martínez Compañón, Obispo de Trujillo", Lima, Mercurio Peruano, vol. xxIX, núm. 259, pp. 421-469.

Varios

Antigüedades del Perú, Madrid, Historia 16, 1992, pp. 143-153.

Vega, Inca Garcilaso de la

Los Comentarios Reales de los Incas, Lima, Librería Internacional del Perú, 1959.

Wheeler, Mortimer

Arqueología de campo, México, Fondo de Cultura Económica, 1978. 